\title{
The Dynamism of Traditional Dance in Mukdahan Province
}

\author{
Peerapong Sensai ${ }^{1}$, Wutthipong Roadkhasemsri ${ }^{1} \&$ Akom Sangiemwiboon ${ }^{1}$ \\ ${ }^{1}$ Faculty of Fine and Applied Arts, Mahasarakham University, Khamriang Sub-District, Kantarawichai District, \\ Maha Sarakham Province, Thailand \\ Correspondence: Peerapong Sensai, Faculty of Fine and Applied Arts, Mahasarakham University, Khamriang \\ Sub-District, Kantarawichai District, Maha Sarakham Province 44150, Thailand. E-mail: psensai119@gmail.com
}

Received: April 29, 2014 Accepted: May 28, 2014 Online Published: June 12, 2014

doi:10.5539/ach.v6n2p106 URL: http://dx.doi.org/10.5539/ach.v6n2p106

\begin{abstract}
This four-year research project examines the modern conditions of traditional dance and its adaptation as a means of conserving and transmitting Northeastern Thai heritage. Document analysis, observation and interviews with the people of Mukdahan found that government policies have supported traditional dance performance since the 1980s. Provincial policy to harness the indigenous culture of eight native ethnic groups has led to the incorporation of the ancient Phu-Tai ritual dance, the Yao, in an adapted form at state sponsored cultural exhibitions, such as the Makham Wan Sai Kong ethnic group festival. The dance is supported by the provincial curriculum and tourist agencies. This paper introduces The 7 in theory to show how traditional dance has been influenced by society and remains an integral part of local culture.
\end{abstract}

Keywords: dynamism, traditional dance, development, social economy, local culture

\section{Introduction}

Isan dance is a vibrant, adaptive and durable cultural performance. Mukdahan Province has a long history of ethnic art and culture. This is due to the extent of immigration into the province caused by conflict, administrative change, resettlement and development of quality of life (Rueangsuwan, 1997). Northeastern Thai (Isan) people created their own identity in the form of ceremonies, homes, language, food, dress, music and actions. Indigenous dance performances were especially important in training the mind and spirit of Isan people, including the Mukdahan inhabitants, as well as broadcasting Isan identity to a wider audience in other domestic and international societies. Dance performance in Mukdahan Province has been adapted to respond to administrative policies and the needs of the audience. This adaptation was important in the creation of a Mukdahan provincial identity and is revealed in the Mukdahan Makham Wan Sai Kong ethnic group festival, which combines the methods of those ethnic minorities that migrated into Mukdahan Province across the Mekong River from Laos. The differences and development of ethnic cultures in Mukdahan Province have created a variety of unique cultural characteristics that are unique to Mukdahan and generate special interest in the province. Additionally, Isan dance performance continuously evolves through media exposure in Thai and global society, via television, the internet or movies. This causes Isan dance performance to further develop. Entertainment businesses that bring local culture to the wider audience considerably aid performance results in a variety of ways, as well as providing reasons and opportunities for performances. Areas affected include policy, vision, mission, community academic or art culture events, contests and competitions, the promotion of tourism festivals, royal, state and official visitor receptions and response to business requirements. These influence the support, sponsorship and development of Isan dance performance. Isan dance performance in Mukdahan province is a part of Thai cultural heritage and is a sign of the prosperity, progress, stability and social peace of the area and the nation. For this reason, the researchers began this investigation to try and assess the nature of dance in the Northeastern region.

\subsection{Dynamism and Culture}

In this study, dynamism has been taken to encompass the movement, adaptation, circulation, coexistence, change, support, conservation, development, repetition, creation and spread of Isan dance in Mukdahan Province (Figure 1). Kritinee Nattawuttisit (2010; Netpokaew, 2004) has explained dynamism and policies of global cultural change, cultural mix and the spread of new culture by studying its global value. Nattawuttisit concluded that global culture does not come from any one place but occurs from the mixture of cultures from different places 
that have their own identity. Thanks to globalization, there are five areas of influence, which are modernization, homogenization, heterogenization, internationalization and decrease of national boundaries. This theory is based on that of Fred Inglis (2004), who argued that cultural dimensions shift throughout the world in attempt to revive and place importance on cultural value (new traditionalism), establish new conservational trends (neoconservatism) and reproduce the past (nostalgia). There is a desire to find goodness and beauty that flourished in the past and has been forgotten by the present. This current has caused a review of history and a search for the roots of culture (essentialism) in order to create a new individual socio-cultural identity that can be transmitted in various forms. A standpoint is thus identified from which to combat fixed society, create acceptance of variety and expand into other areas, such as gender, ethnicity and social class. This creative phenomenon is the spread of 'cultural politics' or the 'politics of identity', which is the 'politics of recognition' for groups in society.

In this study, dynamism has been taken to encompass the movement, adaptation, circulation, coexistence, change, support, conservation, development, repetition, creation and spread of Isan dance in Mukdahan Province.

\begin{tabular}{|c|c|}
\hline \multicolumn{2}{|c|}{4} \\
\hline$\sqrt{7}$ & 7 \\
\hline \multirow{7}{*}{$\begin{array}{l}\text { 1. In Physics, the term 'dynamic' or 'dynamics' } \\
\text { means movement. } \\
\text { 2. In science and engineering the term 'dynamic' } \\
\text { is used to describe the evolution of physical } \\
\text { processes, the movement of gas and the design } \\
\text { of air and spacecraft. } \\
\text { 3. In the humanities and social sciences, } \\
\text { 'dynamics' refers to the creation, spread and } \\
\text { exchange of culture, including its } \\
\text { management, reception and development. }\end{array}$} & \multirow{6}{*}{$\begin{array}{l}\text { The reason for selection of this term was to } \\
\text { encourage multidisciplinary research because it } \\
\text { would broaden the perspective of the research } \\
\text { team. By using the term 'dynamics', the research } \\
\text { team could recognize the importance of natural } \\
\text { factors in the development of society and apply } \\
\text { them to the research. }\end{array}$} \\
\hline & \\
\hline & \\
\hline & \\
\hline & \\
\hline & \\
\hline & \multirow{5}{*}{$\begin{array}{l}\text { 1. Culture is the collective concept of humans in } \\
\text { a society. } \\
\text { 2. Culture is created by humans and can be } \\
\text { learned by and from other humans. Culture is } \\
\text { passed on through thoughts and practices from } \\
\text { one generation to another. } \\
\text { 3. Culture is grounded in symbolic } \\
\text { communication, such as language, ceremonies } \\
\text { and art. } \\
\text { 4. Culture is the collective result of knowledge } \\
\text { and traditional knowledge. } \\
\text { 5. Culture is the way humans define everyday } \\
\text { life and the things around them. } \\
\text { 6. Culture never stands still and is constantly } \\
\text { moved, altered, adapted and developed. }\end{array}$} \\
\hline & \\
\hline $\begin{array}{l}\text { Thai domestic research in the humanities, social } \\
\text { sciences and cultural science. }\end{array}$ & \\
\hline 4 & \\
\hline $\begin{array}{l}\text { International research in the humanities, social } \\
\text { sciences and cultural science. }\end{array}$ & \\
\hline
\end{tabular}

Figure 1. Diagram to explain the use of the term 'dynamism'

Popular culture is the creation, discovery, exchange and repetition of the self (Sucheep Kannasut, 2009). It is the battle of cultural identity and the self. People are in the popular current in order to search for, select and find new identities and deny their affiliation with the traditional stream. This could be a new lifestyle, friendship group, family, workplace or community. This enables the explanation and understanding of social, economic and political phenomena as individual humans fighting to express individuality against the repression of original culture, social status, generation and geography. Popular culture provides the arena and tools for this expression and is, as such, continuous and animated.

Cultural diffusion is a dangerous topic to discuss because many modern anthropologists consider it to be outdated (Goldstein, King, \& Wright, 2009). However, in order to discuss the dynamism of Isan dance, it is necessary to acknowledge and consider the debate. There were three principle schools of cultural diffusionism in the early twentieth century, British, German and American. The British School, led by Grafton Elliot Smith (1933), maintained that all subsequent culture derived from one place (in their case Ancient Egypt). The German 
School of Diffusionism (Ratzel, Graebner) saw that human society 'borrowed' cultures more often than created them and that there were a series of Kulturkreise or cultural origins, rather than just one. The American School of Diffusionism (Kroeber, 1940; Wissler, 1940) coined the term 'cultural relativism' (Locke, 1924; Lowie, 1917), which states that society constrains people and their image of cultural phenomena. Individuals conceive foreign culture in terms of their own. This is a crude and inadequate summary of the three schools and does not detail a century's worth of debate that has occurred since (Harris, 1968; Stocking, 1995; Winthrop, 1991). Such a discussion is regrettably impractical here.

Although social networks are important to spread culture, there are dangers associated with such connections. Assawin Netpokaew (2004) cited three results of globalization: cultural homogenization, cultural heterogenization and cultural hybridization. Globalization as a central model for the spread of culture. The culture is not necessarily Western culture, with aspects of all global cultures gathered into a readily accessible pool. This is a process of social and cultural management made possible by capitalist systems that alters the world in the same direction. As such, it is necessary to manage culture effectively to retain individuality. Dr. Suteera Prasertsan (2009) identified ten important policies for cultural management: management of dominant culture, opinions and faith; cultural management for a self-sufficient social philosophy; cultural management for tourism; cultural management in the media; management of regulations for the creation of culture; cultural management in line with political and administrative policy; cultural management in line with education policy; cultural management in line with religion and belief; cultural management for society and science; cultural management with neighbours.

\subsection{Context of Mukdahan Province}

Mukdahan Province is in the Northeast of Thailand and borders the Lao People's Democratic Republic. Lord Kinnaree founded Mukdahan in 1770, choosing its name after good omens at the time of settlement (Mukdahan Governor's Office, History). During the reign of King Taksin, in 1778, Lord Kinnaree was given the royal title Phya Chanthasrisuraja Uparaja Mandhaturaj, the first Lord of the Realm of Mukdahan. In the process, Mukdahan was declared a city. Originally, Mukdahan fell under the administrative authority of Monton Udon. In 1907, reform to Monton Udon led to the creation of provinces. Under this reform, Mukdahan was made a district of Nakhon Phanom Province. In 1982, Mukdahan was promoted to provincial level, making it the seventy-third Thai province and the seventeenth in the Isan region. The Laos-Mukdahan border is a seventy-two kilometer stretch of the Mekong River, where the river is at its widest in Thailand. The area of Mukdahan is approximately $4,339.8 \mathrm{~km}^{2}$ and is administered into seven districts, which are Mueang Mukdahan, Khamcha-I, Don Tan, Nikhom Kham Soi, Dong Luang, Wan Yai and Nong Sung (Jantrasaka, 2000). The province is 642 kilometers from the Thai capital, Bangkok, and the area is on a high plain. Provincial tourism and trade led to the construction of the second Thai-Laos Friendship Bridge in 2006, leading Mukdahan to be nicknamed the 'Gate to Indochina'. In addition to trade and tourism links, Mukdahan has rich natural resources and an especially diverse culture that includes eight ethnic minority groups: Phu Tai, Tai Ka-So, Tai Yor, Tai Saek, Tai Ka-Lerng, Tai Kula, Tai Kha and Tai Lao.

\section{Research Methodology}

This paper is the culmination of a four-year research product from 2010 to 2013. The focus is on how traditional dance has been adapted and influenced by the provincial social economy of Mukdahan. There were two primary objectives for the investigation, which were: 1) to study the relationship between the social context and dance performance in Mukdahan Province, Thailand; and 2) to study the current state, driving factors, attunement and spread of dance performance in Mukdahan Province, Thailand. The research area was Mukdahan Province, composed of seven districts: Mueang Mukdahan, Khamcha-I, Don Tan, Nikhom Kham Soi, Dong Luang, Wan Yai and Nong Sung. The research tools used for data collection in this research were document analysis, questionnaire, in-depth interview, observation and focus group discussion. Interviews were conducted with a purposively selected group of individuals from the seven districts of Mukdahan Province. The interview respondents are recorded in table 1 (Table 1). The interviews were a set of open-ended questions and two-way communication to find out about the role, conditions and conventions of traditional dance performance in Mukdahan. There were three methods of interview: telephone conversation, un-structured interview and pre-arrange formal meetings. Results obtained regarding the birth, existence and development of Isan dance performance in Mukdahan Province were divided into three sub-categories: a) Isan dance performances in ceremonies and the original beliefs of Mukdahan locals in the seven districts; b) Isan dance performance in the Makham Wan Chai Kong ethnic group festival, which is held annually between the $9^{\text {th }}$ and the $15^{\text {th }}$ of January; c) Isan dance performance at educational institutions in Mukdahan Province that is accepted by Mukdahan locals and famous for the support of its work results. The data was analysed using a SWOT analysis. 
Table 1. A list of respondents interviewed during this investigation

\begin{tabular}{|c|c|c|c|}
\hline Name & Position & Location & $\begin{array}{l}\text { Date } \\
\text { Interviewed }\end{array}$ \\
\hline Mr. Kamsuay & Ban Wan Yai Village & Mukdahan Provincial Hall, Wiwitsurakan Road, & $7^{\text {th }}$ January \\
\hline Mueangkot & Leader & Mukdahan Province, 49000 & 2011 \\
\hline Miss Chanokporn & Professional Publicist from & Mukdahan Provincial Hall, Wiwitsurakan Road, & $7^{\text {th }}$ January \\
\hline Potisan & $\begin{array}{l}\text { Provincial Publicity Office, } \\
\text { Mukdahan }\end{array}$ & Mukdahan Province, 49000 & 2011 \\
\hline Mr. Chanawit & Mukdahan Provincial & Mukdahan Provincial Hall, Wiwitsurakan Road, & $7^{\text {th }}$ January \\
\hline Wisayangkoon & Governor & Mukdahan Province, 49000 & 2011 \\
\hline Miss Napat & Academic expert in culture & Mukdahan Provincial Culture Office, 99 & $8^{\text {th }}$ January \\
\hline Kodsombat & $\begin{array}{l}\text { from Mukdahan Provincial } \\
\text { Culture Office }\end{array}$ & $\begin{array}{l}\text { Pitakphanomked Road, Mueang District, } \\
\text { Mukdahan Province, } 49000\end{array}$ & 2011 \\
\hline Mr. Tawan Piwkam & $\begin{array}{l}\text { Employee of Ban Pao } \\
\text { Cultural Homestay }\end{array}$ & $\begin{array}{l}74 \text { Moo 1, Ban Poo, Ban Pao Sub-District, Nong } \\
\text { Sung District, Mukdahan Province, } 49160\end{array}$ & $\begin{array}{l}29^{\text {th }} \text { October } \\
2012\end{array}$ \\
\hline Mr. Tanitsak Unta & $\begin{array}{l}\text { Director of Mukdahan } \\
\text { Provincial Culture Office }\end{array}$ & $\begin{array}{l}\text { Mukdahan Provincial Culture Office, } 99 \\
\text { Pitakphanomked Road, Mueang District, } \\
\text { Mukdahan Province, } 49000\end{array}$ & $\begin{array}{l}8^{\text {th }} \text { January } \\
2011\end{array}$ \\
\hline $\begin{array}{l}\text { Mr. Teerapiboon } \\
\text { Singra Na Ayutthaya }\end{array}$ & Nongsung District Chief & $\begin{array}{l}\text { Nong Sung District Offices, Moo 4, Nong Sung } \\
\text { Nuea Sub-district, Nong Sung District, Mukdahan } \\
\text { Province, } 49160\end{array}$ & $\begin{array}{l}10^{\text {th }} \text { January } \\
2011\end{array}$ \\
\hline Mr. Pleung Konwai & $\begin{array}{l}\text { Nasameng Subdistrict } \\
\text { Leader }\end{array}$ & $\begin{array}{l}\text { Mukdahan Provincial Hall, Wiwitsurakan Road, } \\
\text { Mukdahan Province, } 49000\end{array}$ & $\begin{array}{l}7^{\text {th }} \text { January } \\
2011\end{array}$ \\
\hline Mr. Pamorn & Chairman of Mukdahan & Mukdahan Chamber of Commerce, 93/25 & $17^{\text {th }}$ January \\
\hline Chaosirikoon & Chamber of Commerce & $\begin{array}{l}\text { Mukdahan-Dondan Road, Sriboonrueang } \\
\text { Sub-district, Mueng District, Mukdahan Province, } \\
49000\end{array}$ & 2011 \\
\hline Mr. Pinit Jaroensuk & $\begin{array}{l}\text { Mukdahan Municipal } \\
\text { Mayor }\end{array}$ & $\begin{array}{l}\text { Mukdahan City Municipal Office, } 80 \text { Song Nang } \\
\text { Satit Road, Mueang District, Mukdahan Province }\end{array}$ & $\begin{array}{l}29^{\text {th }} \text { October } \\
2012\end{array}$ \\
\hline Mr. Phichet & Representative of the & Mukdahan Office of Tourism and Sports, Song & $8^{\text {th }}$ January \\
\hline Dechakampoo & $\begin{array}{l}\text { Mukdahan Office of } \\
\text { Tourism and Sports }\end{array}$ & $\begin{array}{l}\text { Nang Satit Road, Mueang District, Mukdahan } \\
\text { Province }\end{array}$ & 2011 \\
\hline $\begin{array}{l}\text { Mr. Yutitam } \\
\text { Ransimanwong }\end{array}$ & Dongluang District Chief & $\begin{array}{l}\text { Dongluang District Office, } 2287 \text { Alley, Dongluang } \\
\text { Sub-district, Dongluang District, Mukdahan } \\
\text { Province, } 41940\end{array}$ & $8^{\text {th }}$ January \\
\hline Mr. Wimantong & Nongsungwittaya School & Nongsungsamakadeewittaya School, Nongsung & $8^{\text {th }}$ January \\
\hline Yeunyang & Director & District, Mukdahan Province, 49160 & 2011 \\
\hline Mr. Wirot Simporn & $\begin{array}{l}\text { Teacher at Princess } \\
\text { Chulabhorn's College, } \\
\text { Mukdahan }\end{array}$ & $\begin{array}{l}\text { Princess Chulabhorn's College, Mukdahan, Moo } \\
\text { 6, Pang Sai Yai Sub-District, Mueang District, } \\
\text { Mukdahan Province, } 49000\end{array}$ & $\begin{array}{l}27^{\text {th }} \text { October } \\
2012\end{array}$ \\
\hline Dr. Surajit Jantrasaka & $\begin{array}{l}\text { Chairman of Mukdahan } \\
\text { Provincial Culture Office }\end{array}$ & $\begin{array}{l}\text { Mukdahan Provincial Culture Office, } 99 \\
\text { Pitakphanomked Road, Mueang District, } \\
\text { Mukdahan Province, } 49000\end{array}$ & $\begin{array}{l}14^{\text {th }} \text { January } \\
2011\end{array}$ \\
\hline Mr. San & Service Councillor, & Mukdahan Charitable Foundation, 530/1 & $14^{\text {th }}$ January \\
\hline Chaisantitrakoon & $\begin{array}{l}\text { Mukdahan Charitable } \\
\text { Foundation }\end{array}$ & $\begin{array}{l}\text { Samutsakdarak Road, Mueang District, Mukdahan } \\
\text { Province, } 49000\end{array}$ & 2011 \\
\hline Mr. Mai Nongkaen & $\begin{array}{l}\text { Nikomkamsroi Sub-District } \\
\text { Chief }\end{array}$ & $\begin{array}{l}\text { Mukdahan Provincial Hall, Wiwitsurakan Road, } \\
\text { Mukdahan Province, } 49000\end{array}$ & $\begin{array}{l}7^{\text {th }} \text { January } \\
2011\end{array}$ \\
\hline Mr. May Suwannatrai & $\begin{array}{l}\text { Kamcha-ee Sub-District } \\
\text { Chief }\end{array}$ & $\begin{array}{l}\text { Mukdahan Provincial Hall, Wiwitsurakan Road, } \\
\text { Mukdahan Province, } 49000\end{array}$ & $\begin{array}{l}7^{\text {th }} \text { January } \\
2011\end{array}$ \\
\hline $\begin{array}{l}\text { Mr. Ekkarat } \\
\text { Maneekam }\end{array}$ & Nongsung District Chief & $\begin{array}{l}\text { Mukdahan Provincial Hall, Wiwitsurakan Road, } \\
\text { Mukdahan Province, } 49000\end{array}$ & $\begin{array}{l}7^{\text {th }} \text { January } \\
2011\end{array}$ \\
\hline $\begin{array}{l}\text { Ms. Kalinjan } \\
\text { Ramangkoon }\end{array}$ & School Teacher & $\begin{array}{l}\text { Mukdahan Provincial Hall, Wiwitsurakan Road, } \\
\text { Mukdahan Province, } 49000\end{array}$ & $\begin{array}{l}7^{\text {th }} \text { January } \\
2011\end{array}$ \\
\hline $\begin{array}{l}\text { Ms. Sutasinee } \\
\text { Sapawong }\end{array}$ & School Teacher & $\begin{array}{l}\text { Mukdahan Provincial Hall, Wiwitsurakan Road, } \\
\text { Mukdahan Province, } 49000\end{array}$ & $\begin{array}{l}7^{\text {th }} \text { January } \\
2011\end{array}$ \\
\hline
\end{tabular}




\section{Results}

Promotion of the indigenous heritage of Mukdahan was a policy of its second provincial governor, Thanom Chanuwong, who held office between $1^{\text {st }}$ October 1985 and $30^{\text {th }}$ September 1988 (Surajit Jantrasaka, interview, 2011). Under this policy, indigenous people educated Mukdahan locals in the history of ethnic groups. This knowledge was then used as the foundation for provincial events and a means to attract tourism. The modern make-up of community populations in Mukdahan Province is multi-ethnic, an important factor in the dynamism of Isan dance performances. Under the governance of Chanawit Wisayangkoon $\left(27^{\text {th }}\right.$ November $2010-30^{\text {th }}$ September 2012), a four-year provincial development plan was implemented for 2010-2013. The standpoint of the plan was for a 'Trade and Tour Town on the Mekong at the Eastern Gateway to Indochina and Beyond' (Mukdahan Governor's Office, Vision). There were four principal points to the policy:

- Develop trade, investment, tourism and cooperation with neighbouring countries in order to increase Mukdahan capacity and ability to compete.

- Develop human resources, so that society has more knowledge and ability to accept global changes and dynamics.

- Support local customs, traditions, culture and traditional knowledge so that it benefits the economy and society.

- Create balance between economy, society, natural resources and the surrounding environment.

In addition to this vision and in order to achieve administrative success, Mukdahan Province outlined a six-point development strategy:

Strategic Point 1: Development of agriculture and agricultural industries.

Strategic Point 2: Development of tourism.

Strategic Point 3: Development of border trade and relationships with neighbouring countries.

Strategic Point 4: Development of individual and social quality.

Strategic Point 5: Management of natural resources and the surrounding environment.

Strategic Point 6: Maintenance of border strength (Mukdahan Governor's Office, 2010).

Despite its benefits, Mukdahan's problems also come from being a border crossing, especially harm to the environment, cultural dilution and crowds. From interview with Chanawit Wisayangkoon (Chanawit Wisayangkoon, Interview, 2011) it was clear he felt that his vision and set of strategies is under threat from uncertainties and changes caused by encroaching globalization. With the policies in place, all levels of society can be supported, sponsored and developed 'so they may eat well, live well and be happy' (Mukdahan Provincial Development Plan (2010-2013). Yet, according to Wisayangkoon, this can only be achieved if the provincial organizations are offensive in their plans to maximize potential.

\subsection{The Original Indigenous Dances of Mukdahan Province}

Due to inter-marriage and migration, it is now impossible to know which ethnic group the modern people of Mukdahan are descended from, with the exception of those families who have specifically maintained their heritage. Dr. Surajit Jantrasaka (Interview, 2011) believes that 'nowadays, there are probably only six remaining ethnic groups in Mukdahan Province: Phu Tai, Tai Ka-So, Tai Yor, Tai Saek, Tai Ka-Lerng, and Tai Isan (Tai-Lao). Tai Kha and Tai-Kula people can no longer be found in the Province.' The Phu Tai group is currently the most prominent and has the biggest cultural identity in the Province. The traditional Isan dance still found in Mukdahan province despite the changing ethnic make-up is the dance of the Phu Tai Yao ceremony (Worangrat, 1984). Originally, it was believed that sickness and accidents were caused by the spirits or as divine punishment. The remedy for these ills was in the form of an assortment of ceremonies to redress perceived wrongs and appease the spirits. Dance and music were tools with which humans could communicate to the spirit world through the medium of the group leader or the person who accepted responsibility for communication. These mediums, or Mor Yao, were important people in the community and took responsibility for the joining of body and soul by performing and dancing according to their abilities (Tongsawangrat, 1987). Modern ceremonies are not only for curing the sick but also for a variety of other cultural events and exhibitions. During the ceremony, a number of sacrificial objects are placed on a paan, or tray, as offerings. These included rice whisky, whisky, popped rice flowers and other objects, especially money and gold from people making offerings to the spirits. Other aspects of the ceremony are musical instruments, notably Kaen (a set of bamboo mouth pan-pipes), klong (a hand-drum), and other percussion instruments. Nowadays the rite takes place in a ceremonial marquee or 
pavilion and the site is colorfully decorated with flags or fabrics to indicate the ceremonial importance of the stage (Figure 2).

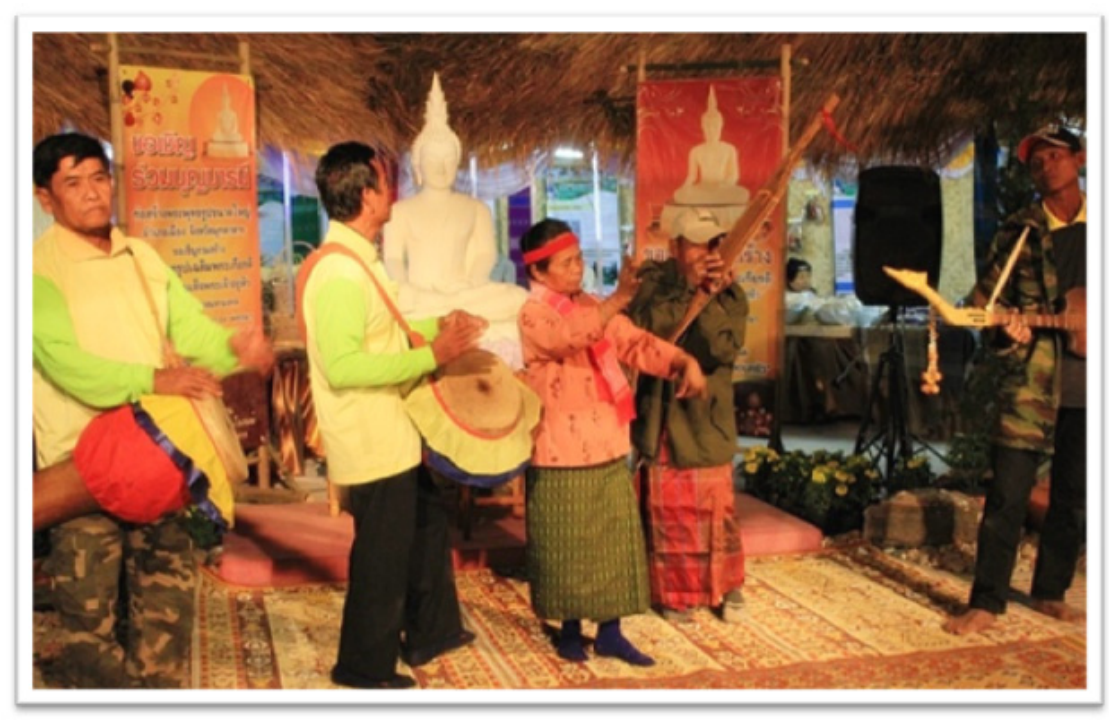

Figure 2. The Yao Ceremony of Mukdahan Province

People in each of the seven districts of Mukdahan province still believe in the Yao ceremony, which is closely tied to religious faith and is a way of curing ills in the family. It is held that the dancing of the medium will appease the spirits by freely alternating movement to the left, right, up and down, rotating their wrists and continuously pressing and releasing their index finger. The Mor Yao will flex, contract and extend their neck to control their head, while moving up and down according to the rhythm of the musical instruments. The dance steps are circular and continuous. Yao is a type of dance to communicate with the spirit world, so, during the dancing and ceremony, the medium also chants to call the spirits.

The Yao dance is distinctive in its three-stage fortune telling segment, yet is similar in principle to the Mor Lam $\mathrm{Pi} F \mathrm{Fa}$ dance of Maha Sarakham Province and the Mamuad dance of Surin Province. Non Yang Sub-district in Nong Sung District also holds an annual initiation ceremony for future Mor Yao. As far as could be determined by this study, such a ceremony is unique. In addition, the Phu Tai people of Non Yang incorporate the Yao dance into the annual Buddhist Ngan boon pawet ceremony. The Yao segment of the ceremony is known as Yao Ao Hoob or Len Ao Hoob Ao Hoy. The dance includes the worship of male and female genital replicas to call for rain. The researchers noticed clear similarities with the Bung Fai dance of Northeastern Thailand, especially the link between human fertility and natural fertility (rain) (Worangrat, 1984).

\subsection{Platforms of Isan Dance in Mukdahan Province}

As a result of government interest in the ethnic heritage of Mukdahan, the Yao ceremony was incorporated into the 'Ngan Ruam Pow Thai Mukdahan Makham Wan Sai Kong', a provincial festival to showcase the ethnic diversity of Mukdahan (Figure 3). The event is now named the Annual Red Cross Festival of Mukdahan and the Yao dance is a popular act among tourists, both domestic and international, because it reveals the original ways of Mukdahan locals. Interviews with heads of musical groups performing the Yao dance highlighted a number of problems with the representation of Yao customs at the festival. Due to time constraints, not all elements of the dance can be included in the performance. Also, because it is a show rather than a genuine ceremony, the performers will not perform the Yao comprehensively for fear of inciting the wrath of the spirits and causing personal catastrophe. This is a form of the dance for conservation. The purpose of the performance is to inform and educate the audience into the existence and methods of the Phu Tai Yao dance, with the assumption made that if the audience wishes to study the custom further, they will pursue their interest at a genuine community ceremony.

On $15^{\text {th }}$ January 2011, Mukdahan held its inaugural 'Chinese New Year: Four Territories, Four Cultures' Festival. The existence of this festival comes from the dedication of four countries, especially people in the towns twinned with and connected to Mudahan, which are Chóngzuǒ in the People's Republic of China, Quảng Trị in the Socialist Republic of Vietnam and Savannakhet Province in the Lao People's Democratic Republic. 
The research team observed the 2012 festival from $20^{\text {th }}$ to $23^{\text {rd }}$ January. The festival was organized by the government, private sector and local communities and presided over by Chanawit Wisayangkoon, then Mukdahan Provincial Governor, Weung Jiejawon, Deputy Secretary General of Chóngzuǒ, Kamla Chaiyawong, a representative of Savannakhet Province and Huong Minghai, Consul of the Socialist Republic of Vietnam. The principal organizing institution was the provincial Chamber of Commerce. Following the opening ceremony of the festival, there were local dance performances by students of Mukdahan School and Nakhon Phanom University, as well as international performances by representatives of the visiting countries. The festival included an EWEC Expo to showcase products from the four countries, including Thai OTOP. It was a rare and valuable display of the indigenous heritage of the eight ethnic groups settling along this stretch of the Mekong River.

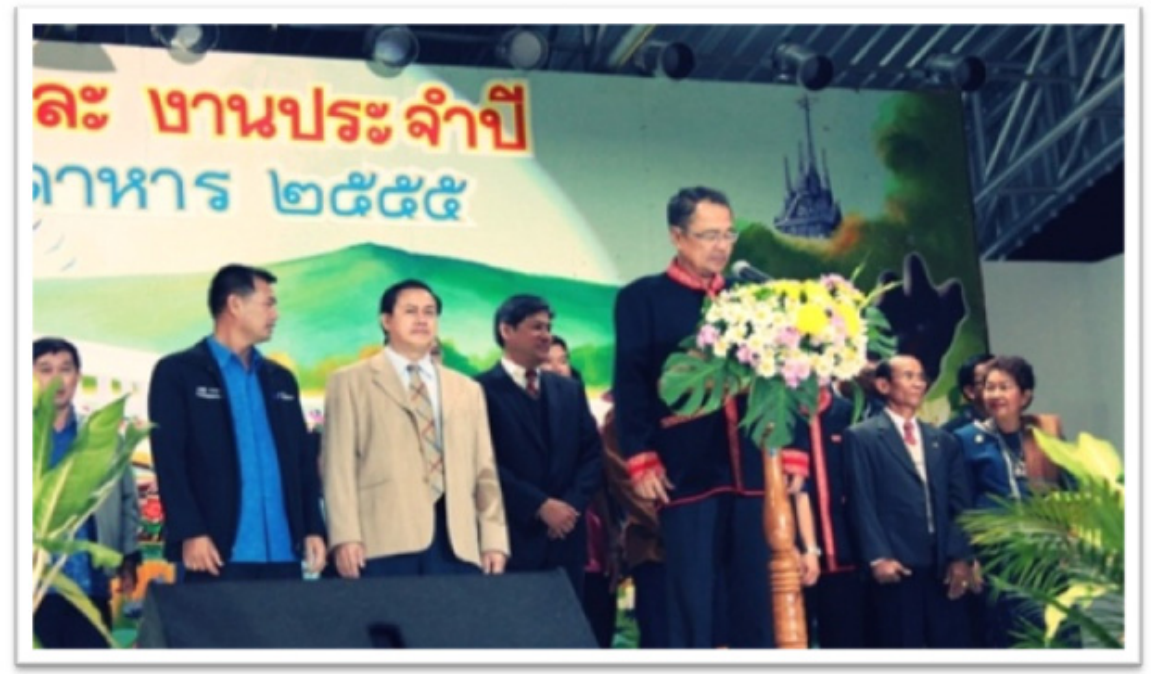

Figure 3. Government officials speaking at the opening ceremony of the annual 'Ngan Ruam Pow Thai Mukdahan Makamwan Saikong' festival

On $15^{\text {th }}$ January 2011, Mukdahan held its inaugural 'Chinese New Year: Four Territories, Four Cultures' Festival. The existence of this festival comes from the dedication of four countries, especially people in the towns twinned with and connected to Mudahan, which are Chóngzuǒ in the People's Republic of China, Quảng Trị in the Socialist Republic of Vietnam and Savannakhet Province in the Lao People's Democratic Republic. The research team observed the 2012 festival from $20^{\text {th }}$ to $23^{\text {rd }}$ January. The festival was organized by the government, private sector and local communities and presided over by Chanawit Wisayangkoon, then Mukdahan Provincial Governor, Weung Jiejawon, Deputy Secretary General of Chóngzuǒ, Kamla Chaiyawong, a representative of Savannakhet Province and Huong Minghai, Consul of the Socialist Republic of Vietnam. The principal organizing institution was the provincial Chamber of Commerce. Following the opening ceremony of the festival, there were local dance performances by students of Mukdahan School and Nakhon Phanom University, as well as international performances by representatives of the visiting countries. The festival included an EWEC Expo to showcase products from the four countries, including Thai OTOP. It was a rare and valuable display of the indigenous heritage of the eight ethnic groups settling along this stretch of the Mekong River.

Traditional dancing is also preserved in the Jao Mae Song Nang Pi Nong ceremony. Local legend tells of two sisters who traveled to the Mukdahan area in 1353, before Lord Kinnaree had established the city (Attanak, 2000). En route, the sisters' boat capsized and they died before reaching safety. When Lord Kinnaree came to settle in Mukdahan in 1770, he discovered the remains of the sisters, which he treasured in a purpose built shrine. Later, when more settlers came to the area they too discovered the remains, which had returned to their original resting place. The villagers realized the sacred nature of the relics and revered the sisters, whose screams can still be heard on the eleventh evening of the waxing moon in the sixth Thai lunar month. In the past Mukdahan locals obeyed a custom of making offerings to two Mother Goddesses at their shrine in November, Jao Mae Song Nang Pi Nong. This included a Thai dance to worship the Goddesses. Over time, the ceremony has been incorporated into the ritual of Jao Paw Jao Fa Moong Mueang (paying respects to the city spirit) and the rituals are held simultaneously at the full moon of the sixth lunar month. Religion was found to play four important roles in the 
prevalence of Isan dance: 1) Religion teaches personal and social discipline; 2) Religion is a cause of social gathering and creates a platform for the dance; 3) Religious rites have continued to the present day and are part of Mukdahan symbolism, which incorporates traditional dance; 4) Religion encourages the expression of emotion and feeling.

One further arena to showcase traditional dance is the Thai-Lao Boat Race from Mukdahan to Savannakhet Province in the Lao People's Democratic Republic. The event is organized by Mukdahan Municipality, the Tourism Authority of Thailand, local organizations and people from Mukdahan and Savannakhet. The competition has greater significance for the local culture of the area and strengthening relations between Thailand and Laos because it is made the main attraction of a three-day cultural festival, including Thai dance. The festival observed as part of this investigation was held from $28^{\text {th }}$ to $30^{\text {th }}$ October 2012 . The following is a transcript of an interview with Pinit Jaroensuk, the Mukdahan Municipal Mayor:

'The boat race of Mukdahan Province is a custom that has been inherited since antiquity. It is held on the Mekong River around the end of Buddhist Lent from the $13^{\text {th }}$ to $15^{\text {th }}$ days of the waxing moon in the eleventh lunar month... This year, we have allowed people from both sides of the border to enjoy open access to the festival by waiving the visa fees...' (Pinit Jaroensuk, Interview, 2012).

From observation of the festival, it was clear that Isan traditional dance remains important in showcasing local art and culture. There is a large dance parade as part of the festival opening ceremony and, given government policy to encourage visitors from Laos and neighbouring Thai provinces, this advertises local dance to a wider audience.

\subsection{The Role of Communications for Isan Dance}

The Office of the National Economic and Social Development Board has established a partnership with the Japan International Cooperation Agency (JICA) to control and support the development of four provinces in the Northeast of the country: Nakhon Phanom, Mukdahan, Kalasin and Sakon Nakhon. Two provinces in the Lao People's Democratic Republic have also been included in JICA's project. The creation of the second Thai-Laos Friendship Bridge as part of this project has made Mukdahan a centre of trade, commerce and tourism. From interviews with the Provincial Governor of Mukdahan, local hoteliers, a representative of the provincial cultural council, the head of the provincial office for the Ministry of Tourism and Sport and chairman of the Mukdahan Provincial Tourism Association the researchers were able to outline four roles that communications have had for the development of Mukdahan: 1) the friendship bridge has made Mukdahan a gate for trade and commerce in Indochina; 2) the friendship bridge has opened Indochina to Thai industries and provided an access for Thai industries to the Eastern seaboard; 3) the friendship bridge has made Mukdahan a centre of finance, academic services, research and technology; 4) the friendship bridge has made Mukdahan a centre of tourism. With this expansion and development, also comes threats and the Province must protect its cultural heritage against the influence of foreign customs, migration, modernization and globalization.

\subsection{Education and Isan Dance in Mukdahan Province}

The education policy of the Thai government has resulted in all schools in Mukdahan Province holding activities in Isan choreography (Figure 4). All schools have stages for Isan dance and continuous development of the discipline. Interviews with dance teachers (Kalinjan Ramangkoon and Sutasinee Sapawong, Interview, 2011) in Mukdahan province showed that the most prestigious Isan dance competition for schools in the annual Northeastern Region Academic Competition, which was held for the $62^{\text {nd }}$ time in 2012, the hundred year anniversary since its inauguration in 1912. This Academic competition begins at the district and local level, with winners progressing to the provincial, then regional and national stages. The competition is taken seriously by all schools and is a wonderful platform to showcase the cultural heritage of Mukdahan traditional dance. Across the province, the development of Isan dance performance is reflected in the production of dance that passes the basic specifications and the process of government officials advancing their academic status by becoming experts. These are impulses that cause the production of new Isan dance performance and continuous spread of the art-form, especially activities that support and develop student ability by giving them real experience. Dance performances during festivals and ceremonies of Mukdahan Province are further evidence of the impulse created by academic institutes for Isan dance performance to continue, adapt, change and develop. 


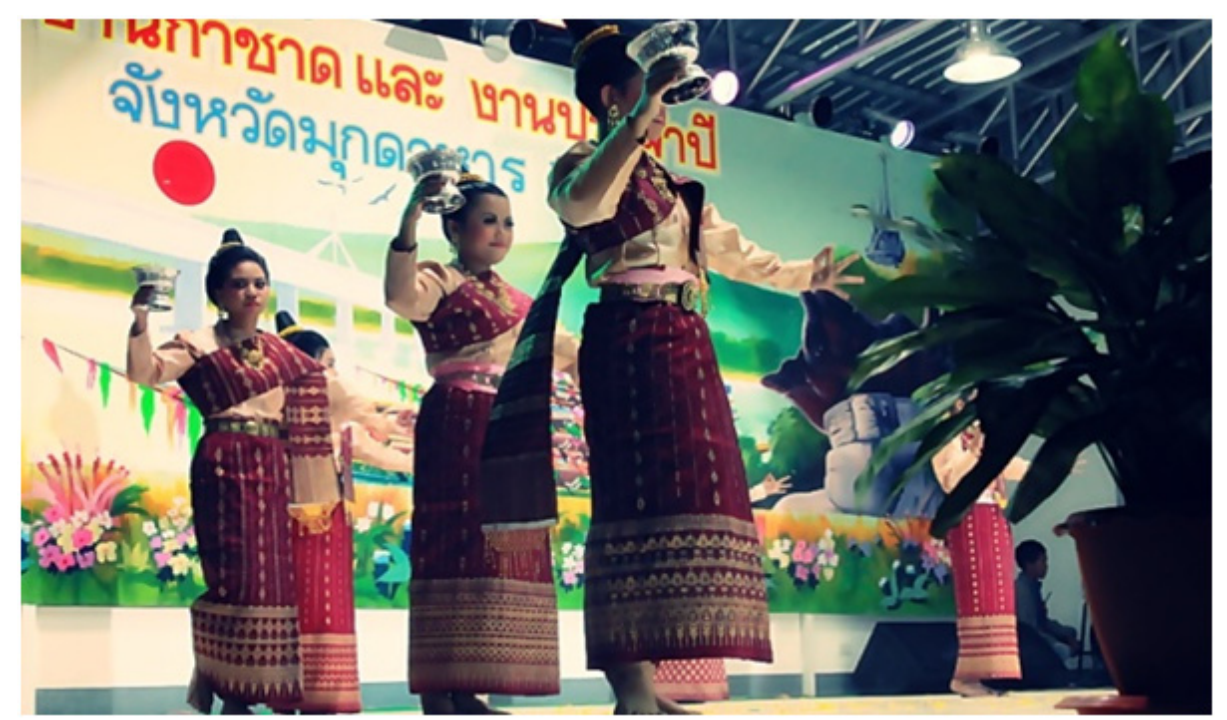

Figure 4. Results of choreography teaching to upper secondary level students in Mukdahan Province

\section{Discussion}

The development of Isan dance is the steps that are taken to protect original Isan dance forms against modern social change. This has been partially achieved in Mukdahan through the implementation of government policies to recognize the importance of indigenous culture and traditional customs. However, there remains need for appeal to related organizations to place importance on the communities as strongholds for provincial development. For this reason, concepts of Isan dance development must aim to strengthen ethnicity and emphasize the dynamic relationship between people and their surrounding environment in response to social change and external influence.

The situation of dance in multicultural Mukdahan Province is consistent with Fred Inglis' (2004) theory because the dance has been continuously supported and developed in line with administrative policy. Drive to revive the value of original customs is a foundation for creating a collective identity, while generating internal and external social acceptance. The research team in this investigation realized the similarities between the Mukdahan Yao ceremonial dance and dances from Kalasin, Sakhon Nakon and Nakhon Pathom. This allowed the researchers to appreciate Isan dance as a response to thought, faith and belief in Northeastern Thailand. This has already been recognized by the authorities who are trying to support inheritance of this valuable heritage by future generations and cement a provincial identity for Mukdahan through the medium of dance.

This investigation revealed a number of interesting points regarding the diffusion of Isan dance. Firstly, the original inhabitants of Mukdahan Province migrated across the Mekong River and introduced their ceremonies and dances to modern-day Thailand (Wannasiri, 2007). However, the natural environment and its spirits are at the heart of the original Yao dance of the Phu Tai people, so location-specific adaptations were made. The patterns of Isan dance correspond to the German theory, given the similarities between the Mukdahan Yao ceremonial dance and dances from Kalasin, Sakhon Nakon and Nakhon Pathom. In light of this, the hypothesis of Assawin Netpokaew (2004) also holds true, which argued that hybrid culture is the most natural progression of human culture, given human tendency to exchange and adopt social practices. Following this investigation, the research team agrees with Sucheep Kannasut's (2009) interpretation of popular culture as a hunt for disassociation with traditional culture. Isan dance in Mukdahan has moved away from its roots by adapting to modern social context and is now found on stages at cultural fairs in a diluted form. The causes of change have been globalization, community expansion, government influence and the modernization of audiences and the locality. Cultural relativism can be used to describe the spread of dance in Mukdahan after it was separated from Nakhon Phanom and promoted to the provincial level in 1982. The Mukdahan locals, who had once been part of the Phra That Phanom worship festival, had to create a new set of cultural practices to create an identity relative to their new status, hence the emergence of policies to promote indigenous heritage during the term of the second provincial governor, Thanom Chanuwong.

The policy to create provincial festivals and customs in Mukdahan Province that has been inherited for over twenty years has caused dance performance in Mukdahan Province to be a mechanism of cure and care, a mechanism of entertainment and a mechanism for supporting tourism. It raises the status of institutions and 
organizations. Dance performance in Mukdahan Province has a role in indicating the progress of society, culture, education, economy and tourism. This enables Mukdahan Province to develop. The researchers are able make the following four conclusions from this macro-analysis: a) dance performance in Mukdahan Province is a mixture of consciousness and experience of Mukdahan people; b) dance performance in Mukdahan Province has the particular characteristics of ethnic groups; c) dance performance in Mukdahan Province has dynamic characteristics and adaptation because Isan dance is creatively choreographed to combat the oppressive nature of society; d) dance performance in Mukdahan Province must be inherited in every area and there must be impulse to pass on Isan dance to future generations. Nowadays, educational institutions have a high influence in the spread and inheritance of Isan dance performance. The Mukdahan government must reform its own policies according to each in Dr. Suteera Prasertsan's (2009) list. In addition to the ten points, provisions must be made for the substantial development of the artistic performance. These provisions must not be limited to clearer definition of organizational roles and must concentrate on raising awareness in each and every member of Mukdahan society, by outlining a strategy, supporting its progress and securing sponsorship. Mukdahan must be the example.

Respect and inheritance of original Isan dance, creative application and adaptation of traditional dance to modern lifestyle can be seen in the communities of Mukdahan Province and the results of government schemes and programs. The researchers have developed the 7 IN Theory to highlight the factors that cause Isan dance to adapt and progress (Figure 5). There are seven areas that drive traditional dance in Mukdahan Province.:

- Intellection: Thought and reasoning processes that actively led to the creation of dance based on demand, including conception, conversation, planning, discovery and practice.

- Institution: Inherited practices and customs that have been continuously passed on and adapted to enable Mukdahan to compete as a multiethnic province in Isan.

- Inquisition: Consideration and appraisal of the characteristics of local dance in Mukdahan that have caused its recognition as part of the provincial identity.

- Instigation: Encouragement and support from government policies have allowed each community to take responsibility for their dance heritage and the conservation of ethnicity in Mukdahan.

- Instruction: Directives from the Mukdahan Provincial Governors have encouraged all villages to participate in the upkeep of their traditional culture.

- Interpenetration: Immigration into Mukdahan has facilitated cultural exchange, spread and development of traditional dance.

- Incubation: Isan dance has grown through the participation and cooperation of the government, the private sector and the local communities.

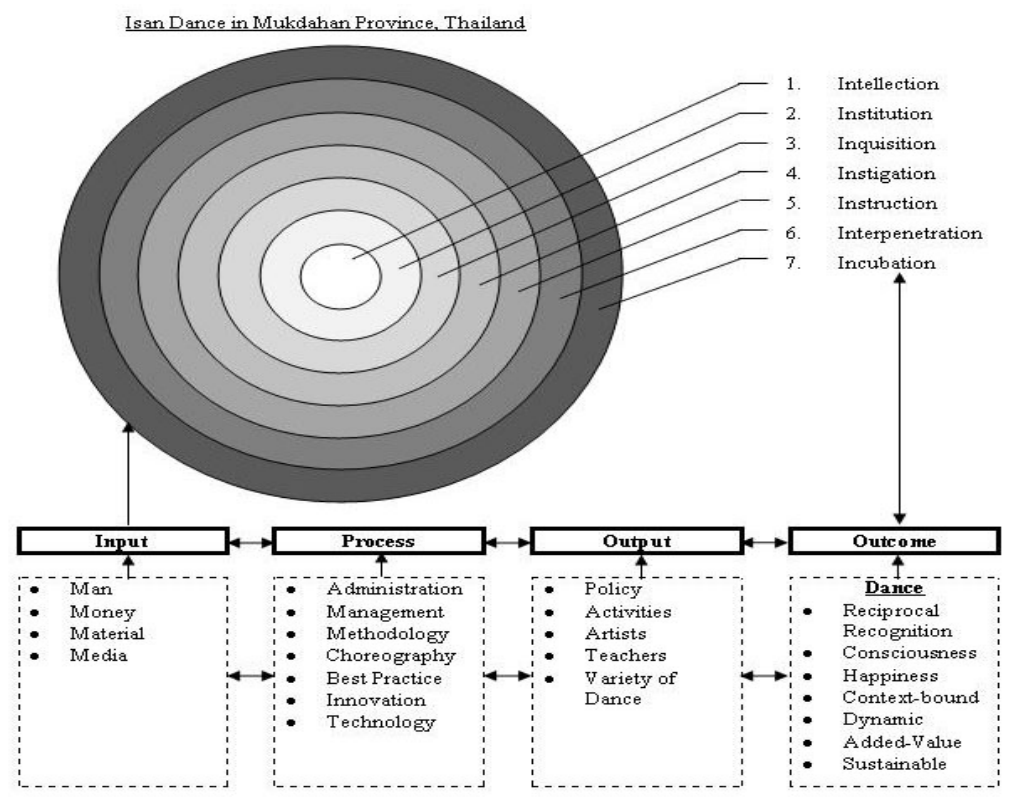

Figure 5. The 7 In Theory: Dynamics of Dance. A conclusion of the factors and influences on the movement impulse of Isan dance performance within Mukdahan Province 
A number of things help the maintenance of original identity and transmission of Isan dance performance to the new generations in a simple and easily adopted format. These are: 1) the factors and characteristics of the transmission of Isan dance performance in Mukdahan Province; 2) respect and inheritance for the art and creation through adaptation of dance to the modern lifestyle so that it may continue in the future; 3 ) presence of Isan dance performance in the communities of Mukdahan Province; 4) activities where the results from academic institutions are presented in combination with everyday life. The new generations have access to the performances in dance processions during cultural festivals and dances upon parade floats. Cultural exchange outside the province counts as a branch in the growth of Isan dance performance. When Isan dance performance moves to other areas and develops in its own right, it causes the new location to develop a strong culture of its own and thus the impulse of Isan dance performance in Mukdahan Province causes adaptive relocation. On this premise, the researchers developed the 7 In Theory, by which Isan dance shows its dynamism.

\section{Acknowledgements}

The researchers would like to thank the Provincial Governor, Chief District Officers, Municipal Mayors, Directors, artists, villagers and townspeople of Mukdahan for agreeing to provide essential data that allowed this research to reach a successful conclusion.

\section{References}

Attanak, P. (2000). Thai-Vietnamese lifestyle in the Mukdahan municipal area [in Thai]. Unpublished doctoral thesis. Princess Maha Chakri Sirindhorn Anthropology Centre, Thailand.

Goldstein, M., King, G., \& Wright, M. Diffusionism and Acculturation. Anthropological Theories: A guide prepared by students for students. Retrieved December 16, 2013, from http://anthropology.ua.edu /cultures/cultures.php?culture=Diffusionism\%20and\%20Acculturation

Graebner, F. (1903). Kulturkreise and Kulturschichten in Ozeanien. Zeitschrift fur Ethnologie, 37, 28-53.

Harris, M. (1968). The Rise of Anthropological Theory. New York: Thomas Y. Crowell Company

Inglis, F. (2004). Culture: key concepts in the social sciences. Cambridge, MA: Polity Press.

Jantrasaka, S. (2000). Mukdahan [in Thai]. Mukdahan: Mukdahan Government Offices.

Kannasut, S. (2009). Popular Culture [in Thai]. Retrieved December 15, 2013, from http://sucheeppost.blogspot.com/2009/05/popular-culture.html

Kroeber, A. L. (1940). Stimulus diffusion. American Anthropologist, 42(1), 1-20. http://dx.doi.org/10.1525 /aa.1940.42.1.02a00020

Locke, A. (1924). The Concept of Race as Applied to Social Culture. Howard Review, 1, 290-299.

Lowie, R. (1917). Culture and Ethnology. New York: D.C. McMurtrie.

Mukdahan Governor's Office. (2010). Mukdahan Provincial Development Plan (2010-2013) [in Thai]. Retrieved December 16, 2013, from http://www.mukdahan.go.th/yuttasart/plane2553_2556).pdf

Mukdahan Governor's Office. (n. d.). History [in Thai]. Retrieved December 16, 2013, from http://www.mukdahan.go.th/history.htm

Mukdahan Governor's Office. (n. d.). Vision [in Thai]. Retrieved December 16, 2013, from http://muk.mukdahan.go.th/eng/Vision2.php

Nattawuttisit, K., et al. (2010). Global cultural dynamism: The effect on Thai culture [in Thai].

Nedpokaew, A. (2004). Cultural Globalization [in Thai]. Matichon Daily News, 27, 9614.

Prasertsan, S. (2009). Cultural management in governmental policies [in Thai]. Journal of the Institute for Culture and Art, 1(19), 41-50.

Ratzel, F. (1896). The History of Mankind. (Trans Butler, A. J.). London: Macmillan.

Rueangsuwan, J. (1997). Thai-Isan People [in Thai]. S.l.

Smith, G. E. (1933). The Diffusion of Culture. London: Watts.

Stocking, G. W. Jr. (1995). After Tylor: British Social Anthropology, 1888-1951. Madison: University of Wisconsin Press

Tongsawangrat, T. (1987). Customs of the Phu Tai people [in Thai]. S.1.

Wannasiri, N. (2007). Humanities, society and culture [in Thai]. Bangkok: Kasetsart University. 
Winthrop, R. H. (1991). Dictionary of Concepts in Cultural Anthropology. New York: Greenwood.

Wissler, C. (1940). Man and Culture. New York, NY: Norwood Editions.

Worangrat, S. (1981). A comparative study of the cultural customs of Phu Tai and Chao So: A case study of Pannanikom and Kusuman Districts, Sakon Nakhon Province [in Thai]. Unpublished doctoral thesis, Silpakorn University, Thailand.

\section{Copyrights}

Copyright for this article is retained by the author(s), with first publication rights granted to the journal.

This is an open-access article distributed under the terms and conditions of the Creative Commons Attribution license (http://creativecommons.org/licenses/by/3.0/). 